\title{
Physical Education Majors Team Teaching in an Early Field Experience in a Junior High School Setting 體育本科生應用團隊教學法於初中體育課
}

\author{
David BARNEY Robert CHRISTENSON \\ Oklahoma State University, Oklahoma, USA
}

大衛賓尼 羅伯特基斯滕森

美國奧克拉荷馬州大學

\begin{abstract}
The early field experience (EFE) has been considered a valuable and important component of a physical education major's education (Curtner-Smith, 1993). For this study 26 pre-service teachers (PST) (physical education majors) team taught (13 teams) in an EFE in a local junior high school. During their EFE each team taught 2 lessons in the school. From this study it was found that during the PST lessons the junior high students were active in the class activities, that the PST should have used louder voices when teaching, that the PST should have had a back-up plan for their lessons, that music played can help during class activities, and that they PST felt their lessons went "well."
\end{abstract}

\section{摘要}

早期的實習教學經驗，對於體育本科生而言是一種有效的學習方法。是次研究共有26位體育實習教師參與團隊式教學法，結 果顯示這種教學法令初中學生更加活躍, 而實習教師需要加大他們説話聲音, 需要準備後備的活動計劃, 在活動中使用適當的音 樂等, 這些改變能夠讓實習教師感到有滿意的教學效果。

\section{Introduction}

When analyzing a physical education teacher education (PETE) program, the early field experience (EFE) should be considered an important component in the students' education. The EFE has been defined as an off campus teaching episode for pre-service teachers (PST), which involves working in the school environment with groups of students. These experiences occur prior to the student teaching experience (Dodd, 1989). With student's working in the school environment during an EFE, Paese (1989) has noted seven advantages that can come from student's participation. They are, a) pre-service teachers can make better career choice, b) field experiences can bridge the gap between theory and practice, c) courses within the curriculum are more meaningful, d) pre-service teachers gain a better understanding of children, e) pre- service teachers gain a better understanding of their responsibilities as teachers, f) pre-service teachers gain a better understanding of their ability to teach children and have the opportunity to develop teaching skills, and g) pre-service teachers realize that there is more to teaching than telling children what to do.

O'Sullivan and Tsangaridou (1992) studied physical education majors conceptions of the teaching and learning process, and their role as teachers, during the EFE. From this study two findings were concluded. First, pre-service teachers can be trained to focus on student learning as a primary goal during the EFE. And second, a well constructed EFE can help students better understand teaching, and their role as a professional teacher as they work with students. 
Another component that has been gleaned from the literature is what the PST feel is important for them to do while they are participating in the EFE. Barney and Pleban (2006) studied perceptions of PST before and after a semester long early field experience. For this study the researchers interviewed the PST before they participated in their EFE and then interviewed them again after they completed their semester long EFE. It was found that the PST was most concerned with, 1) classroom management, 2) classroom preparedness, 3) student learning and 4) making physical education an enjoyable experience for the students.

LaMaster (2001) investigated an early field experience with a service learning component in the high school physical education setting. For this study PST taught non-traditional games (ultimate frisbee, pickle ball, and modified lacrosse) in a high school setting. None of these units had been taught in the high school previously. The researchers and PST hoped the activities would increase student motivation and greater participation. It was found the high school students enjoyed the exposure to the non-traditional games, and at the same time the EFE benefited the PST.

When analyzing the literature, the main component of these studies had a PST teaching by themselves in the EFE. Not much, if any, of the literature has investigated an EFE where PST teaches in a team teaching situation. For this reason, the purpose of this study was to investigate the EFE where PST team teaching took place in the junior high, and also investigate if it is a viable method of preparing future physical education teachers.

\section{Methods}

\section{Participants \& Context}

Twenty-six pre-service physical education teaching majors (16 males \& 10 females) voluntarily participated in this study. The PST within the class self-selected the partner they would be teaching with. The 26 pre-service physical education majors were enrolled in a spring semester methods of teaching secondary physical education class required for graduation. During the methods of teaching secondary physical education class the PST were instructed on lesson planning, classroom management, teaching styles, safety, and instructional effectiveness. Previous to the EFE, the 26 PST participated in multiple classroom observations and one opportunity to teach a lesson to their peers during the secondary methods class. This team teaching experience was the first organized college experience the PST had teaching in front of "real" students. The Junior High School (Grades 8 \& 9) used in this study was located in an urban southern city; with an average class size of 21 students. Each lesson that was taught by the PST was observed by the researchers along with the classroom teacher observing every lesson. Prior to the team teaching experience, the PST were required to go and observe two class periods at the junior high. The purpose of having the PST participate in this observation was to get them familiar with the students, the classroom teacher, and gymnasium in which they would do their team teaching. After the students had completed their observations, they would briefly visit with the classroom teacher and discuss their lessons for their team teaching experience. Upon completion of these preparatory steps, the PST teamed up with a classmate for their EFE. The PST then picked two class periods that they would teach at the Junior High School. It was suggested that the PST teach both lessons to the same class. The reason for this was that by the second lesson the PST should be more familiar with the students, and the students would be more familiar with the PST. University Institutional Board (IRB) approval was obtained prior to the start of the study. All pre-service physical education teaching majors signed informed consent forms to voluntarily participate in this study after IRB approval.

\section{Data Collection \& Analysis}

For this study qualitative methods were employed in gathering data (Locke, Silverman \& Spirduso, 1998). They were: 1) informal interviews with the PST after they finished teaching their lesson; 2) written reflections by the PST after they taught their lessons and 3) formal observations by the researcher.

\section{Informal Interviews}

The informal interviews took place after each of the PST lessons. Such questions asked to the PST were, "How did you feel about your lesson?", "What part(s) of your lesson went well?', "What part(s) of your lesson did not go as planned?", "What would you have done differently with your lesson?" Because these informal interviews took place after the lesson, many of these questions were easily answered. Generally, the length of the informal 
interviews with each team lasted from 5 to 10 minutes. The length of each interview depended upon the responses each team gave. After the informal interviews were completed, the researcher transcribed the key points.

\section{Written Reflections}

At the conclusion of every team's lesson, the researcher asked the PST to write a reflection on their lesson. Again, the PST was asked to reflect, from their perspective of the lesson they taught. Such questions the PST would take into account when writing their reflections were, "How the lesson went", "What they thought went well", "What they thought would have made the lesson better", and they were asked to think of all parts of the lesson as they wrote their reflections. The researcher also asked the PST to sit down with their partner they taught with and discuss the above mentioned questions. This gave each team teaching member their partner's perspective after talking over their lesson together. The purpose of having the students write their reflections after the lessons was because of the passing of time, thus the PST could reflect upon what had happened during their lesson.

\section{Formal Observations by the Researcher}

The researcher observed all lessons taught by each team of PST. During this time of observation, the researcher was able to write down notes used for analysis and also used when the PST were informally interviewed after their teaching. From the notes taken from the informal interviews, the written PST reflections and the recall from classroom observations and notes the researcher was able to read, re-read and reflect upon the data to create common themes from the data (LaMaster, 2001; O’Sullivan \& Tsangaridou, 1992).

\section{Results}

During the informal interviews and in the written reflections, the PST was asked to write or comment on how their teaching episodes went from their perspectives. The following themes of: a) Student's Being Active during Class Time Activities; b) Using a Loud Gym Voice; and c) Over Planning or Having a Back-up Plan and d) Miscellaneous thoughts came forward in the analysis.

\section{Students Being Active During Class Time Activities}

Throughout the informal interviews and written reflections of the PST the most common theme dealt with a majority of the students being active during a majority of class time. When analyzing the written reflections regarding student activity, the PST used such phrases as, "Almost all students were active" or "All the students were active at some time during the lesson focus", and "many of the students listened to the instructions, and surprisingly, got into the activity." During the informal interviews some of the PST stated, how surprised they were that the students participated in the activities. One student said she was "totally blown away" when the class got into activity, and found that all of the students were participating. Another student stated how he was nervous at the start of his lesson, but followed his lesson plan and noticed at the level of concentration some of the students had as they were practicing the given skill. He stated that "because they were so focused on practicing the skill and I was so nervous, I didn't notice if there were any classroom management issues that had to be addressed. The students were too busy working on the skill." 
Table 1. Student Response from Team Teaching Experience in the Junior High School.

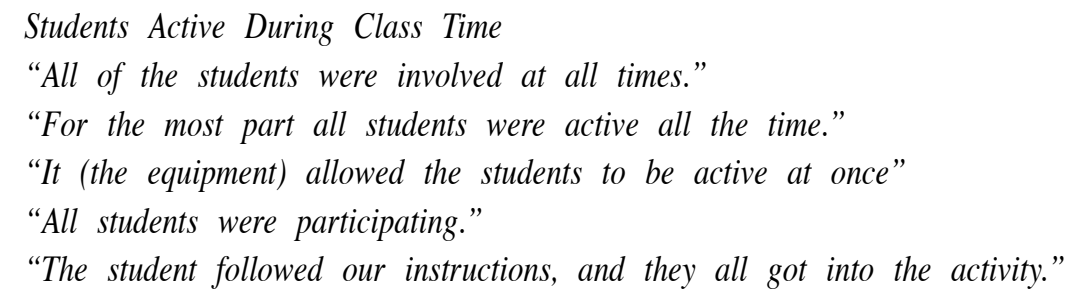

Using a Louder Voice during Class

"It (the lesson) went well, yet I should have talked louder when giving instructions."

"Because my voice wasn't loud enough, it created some confusion on the student's part."

Over Planning of Having a Back-Up Plan

"It never hurts to over plan."

"We needed to have a back-up plan, because we had more time at the end of our lesson."

\section{Miscellaneous Thoughts from the EFE}

"We were both a little worried when we started our lesson."

"It was nice working with Jane (pseudonym). I was nervous."

"It was a lot better working with 'real students', then teaching my classmates."

"We felt this experience was valuable and gave us a better perspective of teaching junior high students."

"The music sure helped get the student going."

"I wished we had used music during our lesson."

\section{Using a Louder Gym Voice}

A second theme that came forward when analyzing the notes from the informal interviews, PST written reflections and observations, was that the PST felt they should have used a louder voice while they taught in the gymnasium. As mentioned above, many of the PST was happy with how the students favorably responded to commands given. Yet, many of the PST still felt they should have had a louder voice during the teaching of their lessons. One PST felt that because she did not have a louder voice it "created some confusion on the student's part." One student said that in her first lesson she was nervous being in front of the students, thus she felt that was why her voice was not loud. By the time she taught her second lesson, she had "overcome her nervousness" and felt she had a louder voice during her lesson. The researcher observed that some of the PST voice wasn't loud enough for the students to hear. Because of this it was observed that when the PST finished giving instructions, students were then told to get into activity. Only to find some students would look around, not sure what they were supposed to do, because they did not clearly hear the instructions.

\section{Over Planning or Having a Back-Up Plan}

Another theme that came from the PST was that they wished they would have over planned or had a back-up plan for their lesson. One team mentioned during their informal interview that they had run out of activities for their lesson. As they realized they had finished teaching their lesson they still had 10 minutes left in the class period. One of the team members said that when they had completed their lesson and still had time left during the period, they had the students participate in an activity that was used earlier in the period. The team felt that the repeated activity went well because the students didn't seem to mind. Another team stated that they learned "it was important to have back-up activities ready". This team had to modify an activity and because they modified the activity it shortened the activity, thus leaving extra time at the end of the class. One of the team members said, "Luckily I remembered an activity from a previous class I had taken, so we used it at the end and it got us through the class." 


\section{Miscellaneous Thoughts from the EFE}

A final theme that came from the data dealt with miscellaneous thoughts from the PST team teaching experience. The most common PST response in this category was that the PST expressed being nervous as they were to teach their lessons. For the PST, this team teaching experience was the first time they had been in front of "real" students. It was observed that one PST was visibly nervous and had expressed her anxiety, but in the same breathe stated that she was glad she was teaching with a partner. Another common student response from the PST was how glad they were to participate in this team teaching experience. One PST expressed it when she said that the experience was "valuable and worthwhile and a good opportunity to be with 'real kids.' Another student said that they were "tired of teaching their classmates and was glad to be in a real school." Another response that was common among the PST was the use of music or lack of music played during their lesson. One team stated that because they had music at the start of the lesson, it "helped get the students going." Another student stated during the informal interview that a couple of the students mentioned how much they liked having the music on while they were participating in the activity. One team member wished she would have had music on when she stated, "Music would have been a good addition to put in our lesson." A final response common among all the PST was that they felt their lessons went well. After all the stress and anxiety the PST went through preparing lessons, lining up equipment for their lessons, and overcoming being nervous, they felt their lessons were successful. Many PST stated that they felt their "lesson went well." One team stated after they got over their nervousness, "things ran smoothly." One student went as far as saying that their lesson was "great."

\section{Discussion}

The PST voices can be valuable to the physical education teacher educator (Graham, 1995), in that they express how to better prepare them to be successful physical educators. The purpose of this study was to investigate the EFE when PST teams teach in a school setting. The researcher found the PST responses to what they thought would have made their lesson better helpful for the fact that it can better help prepare the PST for their team teaching experiences. The themes that came out from the reflections, informal interviews and observations are not difficult to teach and prepare students for, yet, if not prepared, the PST will go into the EFE with little success. The researchers were pleasantly surprised when the PST overwhelmingly stated how they felt that all, if not many of the students were in activity during class. These statements are from the perspectives of the PST, had no statistical data to reinforce this. Yet, these results are in accord with Simon-Morton, McKenzie, Stone, Mitchell, Osganian, Strikmiller, Ehlinger, Cribb \& Nader (1997) findings that suggested that $50 \%$ of physical education class time should be spent in activity time. The researchers found it interesting that the PST felt they needed to have a louder voice in the gym and that it is important to over plan or have a back up plan when teaching. With more experiences the PST has these two themes will become more common as they have more opportunities to teach. From this study the researchers feel pairing the PST together is a viable and practical method of preparing PST. The researchers also feel this method of pairing students is not the "only" or "best" method for having PST work with students in the public school setting. The pairing of PST together can serve as a progression that can better prepare PST for their student teaching experience and for their first years of teaching. As PETE faculty are mindful to the themes that the PST voiced in this study, this will only better prepare them for their EFE a school setting.

\section{Implications of this Study}

After analyzing the PST reflections, informal interviews and observations, some interesting implications for PETE faculty can be gleaned from this study. The first being, the importance of keeping students active during class activities. Many of the PST mentioned that many of the students were activity during the class period. And because the students were on-task with the activities the PST had for them to do, there was little to no classroom management problems. Another implication that has come from this study dealing with classroom management is the use of music being played during the activities. A couple of the PST felt that having music on during class "got the students going" and that the students "liked having music" on during class. This is a good indication that music could be used to help encourage students to be active and keep them focused on class activities. 
Another implication from this study is that PETE faculty should get their students into a school setting for an EFE (Curtner-Smith, 1993). Many PST express being nervous as they participated in their EFE, yet, they enjoyed the experience. Because they were put into teams the PST had to work together and in some cases rely on each other during their lessons. The literature dealing with the EFE has had the PST participating by themselves (O'Sullivan \& Tsangaridou, 1992; Curtner-Smith, 1996; LaMaster, 2001) and this study has suggested putting PST into teams for their EFE. Whatever method works well for the PETE faculty situation, they need to put their students in a school setting working with "real students."

\section{References}

Barney, D., \& Pleban, F. (2006). Pre-Service physical education teacher's perceptions of teaching before and after a semester long elementary physical education practicum experience. The Physical Educator, 63, (1), 46-52.

Curtner-Smith, M.D. (1993). An examination of a generic field experience from a physical education perspective. The Physical Educator, 50, 151-168.

Curtner-Smith, M.D. (1996). The impact of an early field experience on preservice physical education teachers' conception of teaching. Journal of Teaching in Physical Education, 15, 224-250.

Dodds, P. (1989) Trainees, field experiences, and socialization into teaching. In T.J. Templin, \& P.G. Schempp (Eds.), Socialization into physical education: Learning to teach (pp. 81-105). Indianapolis, IN: Benchmark.

Graham, G. (1995). Physical education through student' eyes and in students' voices: Implications for teachers and researchers. Journal of Teaching in Physical Education, 14, 478-482.

LaMaster, K.J. (2001). Enhancing preservice teachers field experiences through the addition of a service-learning component. The Journal of Experiential Education, $24,27-33$
Locke, L.F., Silverman, S.J., \& Spirduso, W.W. (1998). Reading and Understanding Research. Thousand Oaks, CA: Sage Publications.

O’Sullivan, \& Tsangaridou, N. (1992). What undergraduate physical education majors learn during a field experience. Research Quarterly for Exercise and Sport, 63, (4), 381-392.

Paese, P. (1989). Field experiences and competencies for the future physical education teacher. CAHPERD Journal, 52, 18-20.

Simon-Morton, B.G., McKenzie, T.J., Stone,E., Mitchell, P., Osganian, V., Strikmiller, P.K.,Ehlinger, S., Cribb, P., \& Nader, P.R. (1997). Physically activity in a multiethnic population of third graders in four states. American Journal of Public Health, 87, 45-50.

\section{Correspondence:}

David Barney, Ed.D.

Associate Professor

Oklahoma State University

187 Colvin Center

Stillwater, Oklahoma 74078, USA

(405) 744-2025

(405) 744-6507 Fax

David.barney@okstate.edu

Robert Christenson, Ed.D.

Assistant Professor

Oklahoma State University

188 Colvin Center

Stillwater, Oklahoma 74078, USA

(405) 744-5502

Robert.chirstenson@okstate.edu 